\title{
Statyba
}

\section{OPERATIONAL SAND STIFFNESS FROM LARGE- SCALE LOAD TESTS ON RECONSTITUTED SAND BEDS}

\author{
L. Gabrielaitis , M. Jamiolkowski , D. C. F. Lo Presti \& I. Puci
}

To cite this article: L. Gabrielaitis , M. Jamiolkowski , D. C. F. Lo Presti \& I. Puci (2000) OPERATIONAL SAND STIFFNESS FROM LARGE-SCALE LOAD TESTS ON RECONSTITUTED SAND BEDS, Statyba, 6:5, 357-365, DOI: 10.1080/13921525.2000.10531614

To link to this article: https://doi.org/10.1080/13921525.2000.10531614

Published online: 26 Jul 2012.

Submit your article to this journal $₫$

Џ Article views: 90

4 Citing articles: 1 View citing articles 


\title{
OPERATIONAL SAND STIFFNESS FROM LARGE-SCALE LOAD TESTS ON RECONSTITUTED SAND BEDS
}

\author{
L. Gabrielaitis', M. Jamiolkowski ${ }^{2}$, D. C. F. Lo Presti ${ }^{3}$ \& I. Puci ${ }^{4}$ \\ Vilnius Gediminas Technical University ${ }^{l}$, Politecnico di Torino, Italy ${ }^{2.3,4}$
}

\section{Introduction}

Two large-scale experiments have been performed at the ELSA laboratory (JRC, Ispra) in the framework of the research project TRISEE (3D Site Effects of Soil-Foundation Interaction in Earthquake and Vibration Risk Evaluation) funded by the European Commission under the Environment and Climate Programme. These experiments have been described in previous Reports and papers, SGI [1] Negro et al. [2], Pedretti [3], and Jamiolkowski et al. [4].

These experiments consisted of the following steps: i) preparation and saturation of a large-scale sand sample; ii) instrumentation of the sample in order to check the spatial uniformity of $D_{R}$ and to measure vertical $\left(\sigma_{v}\right)$, horizontal $\left(\sigma_{h}\right)$ and pore $(u)$ pressures; iii) construction of a very rigid foundation at the top of the sand bed; iv) application of static load; v) application of a time varying horizontal force and moment; vi) application of horizontal cyclic load (and moment) of increasing amplitude.

This paper briefly describes the experiments with emphasis on the application of static loads and mainly deals with the interpretation of the load-settlement curves. The load displacement curves and the secant elastic stiffness values inferred from each test have been compared to those determined from Plate Load Tests (PLT) performed in Calibration Chamber (CC) by means of a deep circular footing resting on reconstituted Ticino sand samples [5]. Moreover, the observed settlements were compared to those inferred from conventional computation methods $[6,7]$. Creep settlement was also computed. The coefficient of secondary compression $C_{\alpha \varepsilon}$ was inferred from the long term stage of PLT's in CC and a conventional two-minutes primaryconsolidation time was assumed.

\section{Experimental set-up}

\subsection{Physical model}

The experimental prototype consists of a $4.6 \mathrm{~m}^{2}$ in plan and $4.05 \mathrm{~m}$ in height concrete caisson. The lateral boundaries of the caisson are rigid and waterproofed (Fig 1).

A rigid steel plate of $1 \times 1 \mathrm{~m}$ represents the shallow foundation. A concrete layer is interposed between the rigid steel foundation and the sand bed.

The foundation is embedded $1 \mathrm{~m}$ into the sand and a steel 1 metre high formwork is placed around the foundation in order to retain the sand.

The vertical load ( $300 \mathrm{kN}$ for dense sand condition and $100 \mathrm{kN}$ for loose sand condition) was applied to the foundation by means of air cushions. Ticino sand is retrieved from the banks of Ticino river near the city of Pavia and processed for elimination of fines prior to testing. This is a uniform coarse-to-medium silica sand with prevalently subangular grains having sphericity from 0.7 to 0.8 [8]. The index properties of this sand can be summarised as follows: $D_{50}=0.55 \mathrm{~mm}$, $U_{c}=1.6, G_{s}=2.684, e_{\min }=0.931$.

Over the past decade, this sand has been subjected to intensive conventional laboratory and Calibration Chamber testing. The results of such tests have been reported by Baldi et al. $[9,10,11]$, Bellotti [ $[12$, 4] and Lo Presti et al. [13].

\subsection{Description of the experiments}

The sample was reconstituted by pluvial deposition using a travelling sand spreader like those described by Passalacqua [14], Tatsuoka et al. [15], Fretti et al. [16] and Lo Presti et al. [17].

The pluviator consists of a hopper that moves back and forth over the caisson at a constant velocity. The 


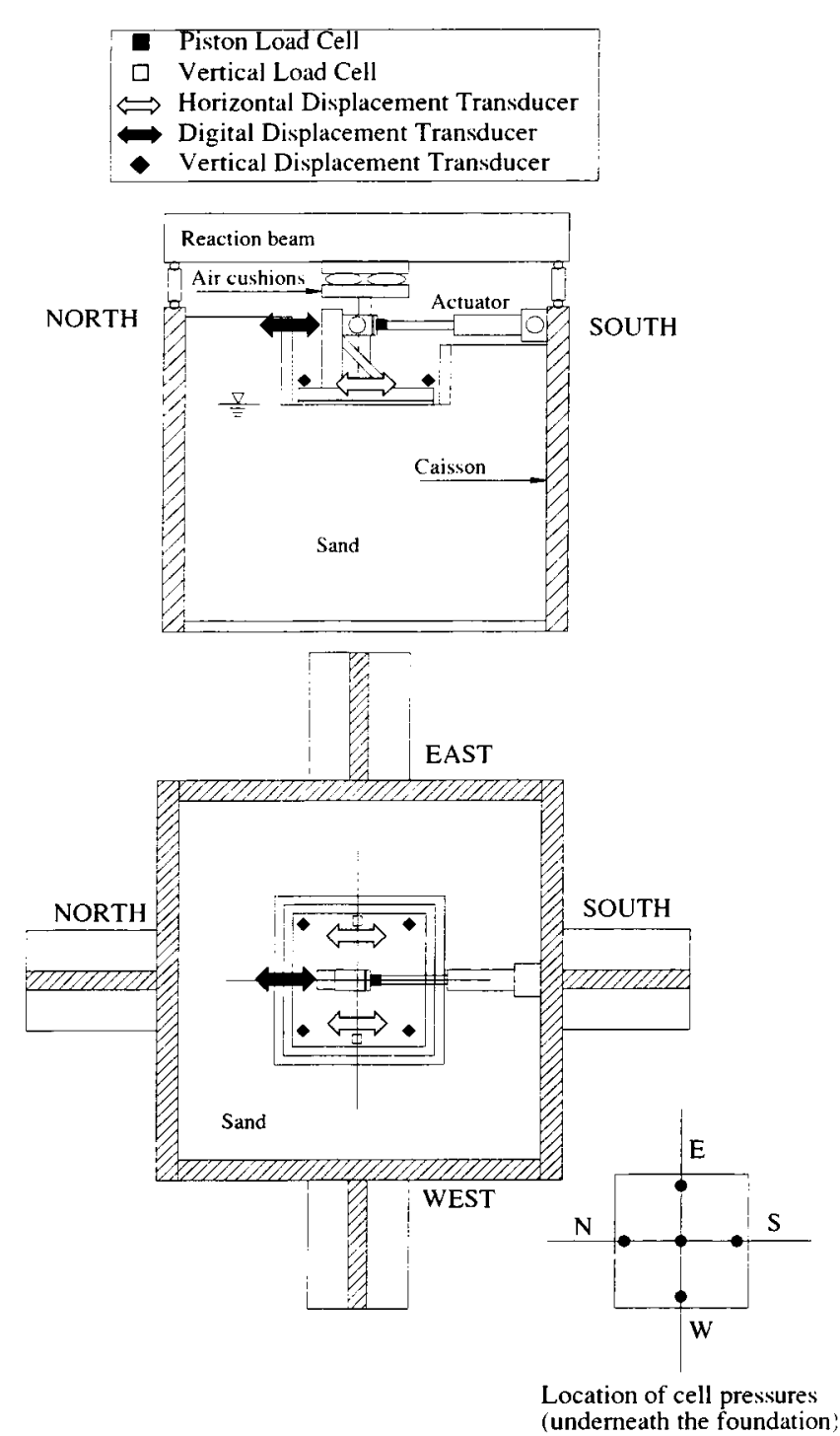

Fig 1. Sketch of the experimental prototype

lower part of the hopper has an opening whose width can be regulated. Meshes can be located beneath the opening for a more uniform spreading of the sand rain. It was decided to use a travelling speed of $1.7 \mathrm{~cm} / \mathrm{s}$ and a variable falling height (i.e. the distance between the deposition plane and the hopper), between 75 and $150 \mathrm{~cm}$. Table 1 summarises the other test conditions for sand deposition.

Table 1. Test conditions for sand deposition

\begin{tabular}{c|c|c|c}
\hline Density & $\begin{array}{c}\text { Opening } \\
\text { width mm }\end{array}$ & $\begin{array}{c}\text { Mesh } \\
\text { opening mm }\end{array}$ & $\begin{array}{c}\text { Thickness of } \\
\text { strata mm }\end{array}$ \\
\hline HD & 3.8 & 3 & 30 \\
\hline LD & 7.1 & no mesh & 70 \\
\hline
\end{tabular}

After the reconstitution of the first three metres of the sample, the steel plate was positioned on top of the sand bed. The foundation was placed horizontally, and a rough interface (cement and sand) between the steel plate and the sand was created, to properly represent friction.

The vertical pressure due to the self weight of the foundation was about $9 \mathrm{kPa}$. The vertical pressure due to the upper metre of sand was, on average, $16 \mathrm{kPa}$.

After the completion of the sample, the process of saturation was started. The water was slowly flushed into the soil from the bottom up to the foundation level by means of a grid of tubes embedded in a bottom gravel layer $110 \mathrm{~mm}$ thick, separated from the sand by a geo-textile sheet. The resulting flow was about 700 $\mathrm{l} / \mathrm{h}$ for the HD specimen and $300 \mathrm{l} / \mathrm{h}$ for the LD specimen. De-aired water was used to achieve a better saturation degree. The flow was maintained for three days.

A section parallel to the $\mathrm{N}-\mathrm{S}$ direction and distant about $80 \mathrm{~cm}$ from the West side was instrumented to assess the uniformity of soil density (Fig 2). In particular the following sensors were placed:

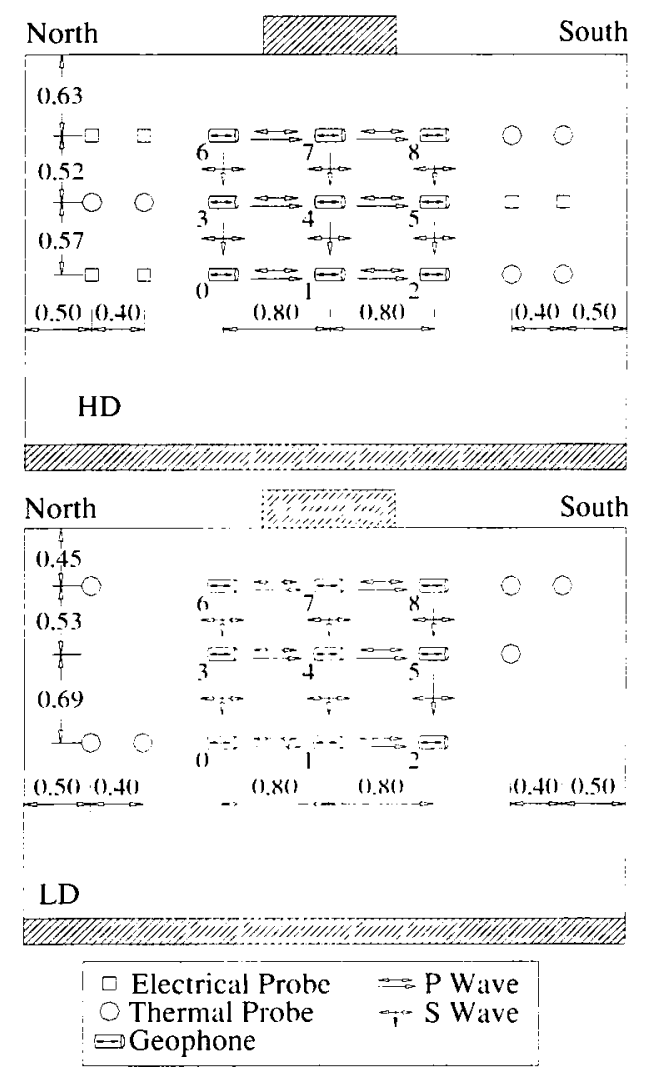

Fig 2. Sections of HD and LD samples for the local check of soil density 
- 9 minigeophones (waterproofed) to assess density and saturation of the sample by measuring the shear and compression wave velocities $\left(V_{s}, V_{p}\right)$.

- 6 thermal and 6 electrical probes for the local check of the sample density.

A check of the sample density was also carried out performing several cone penetration tests (CPT) by means of a standard cone. CPT locations are shown in Fig 3.

Other instruments were placed to measure the applied forces, the horizontal and vertical displacements of the foundation and the stress distribution underneath the foundation. In particular, five pressure cells underneath the foundation, four vertical displacement transducers at the corners of the foundation, two horizontal displacement transducers on the foundation. two load
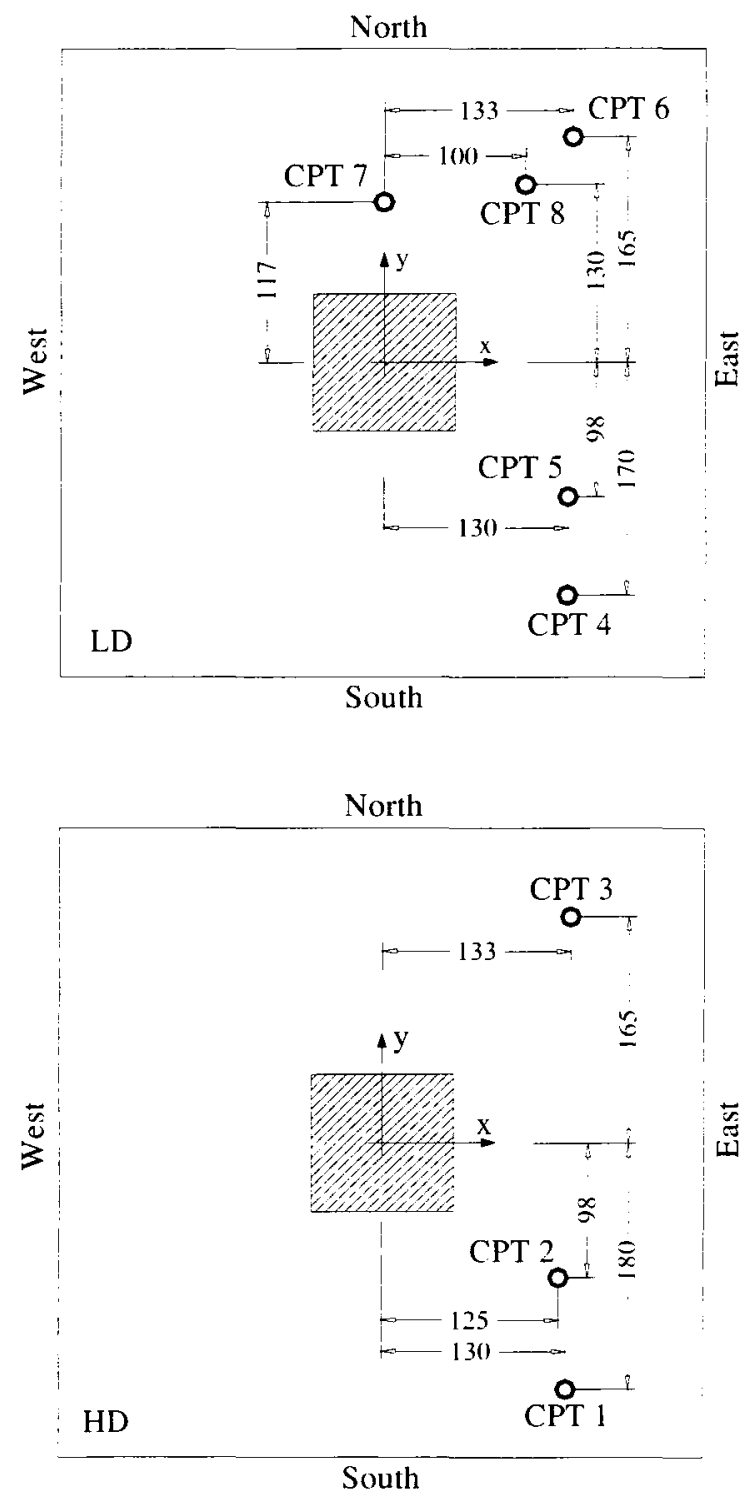

Fig 3. Location of CPT's cells for vertical force and one load cell for horizontal force were installed (Fig 1). Moreover, various pressure cells were embedded into the soil for measuring vertical and horizontal stresses.

In the present paper, the sample uniformity checks and the load-settlement data are discussed.

The global soil density was checked by means of seismic tests that were performed at different stages, i.e. after the reconstitution of the first three metres of the sample; after sample completion, after saturation; after the application of static loading and after the application of cyclic loading. The propagation velocity of compression and shear waves was determined by using an array of three geophones. The geophone located at one end of the array was used as a source and the other two as receivers. The time delay $(t)$ between the arrivals of the wave at the two receivers at known distance $(L)$ allowed one to estimate the wave propagation velocity as $V=L / t$.

Shear wave velocities were estimated at three different locations. Compression wave velocities were determined at three different depths (Fig 2). The soil density or void ratio was computed from the following equations expressing the dependence of the body wave velocity on type of soil, void ratio and applied effective stresses (Lo Presti and O'Neill [18], Roesler [19], Stokoe et al. [20], Bellotti et al. [4]):

$$
\begin{aligned}
& V_{s}=C_{s} \sqrt{F(e)} \cdot\left(\sigma_{a}^{\prime}\right)^{n} \cdot\left(\sigma_{b}^{\prime}\right)^{n} \\
& V_{p}=C_{p} \sqrt{F(e)} \cdot\left(\sigma_{a}^{\prime}\right)^{n} \cdot\left(\sigma_{b}^{\prime}\right)^{n}
\end{aligned}
$$

where: $\left(\sigma_{a}^{\prime}\right),\left(\sigma_{b}^{\prime}\right)=$ normal effective stresses acting along the direction of wave propagation and that of particle motion respectively; $F(e)=$ void ratio function: $C_{s}$ and $C_{p}=$ material constants which depend on the type of soil, anisotropy and on the adopted unit system: $n=$ stress exponent.

In the case of Ticino sand, the following values can be assumed for the parameters of equations (1) and (2) (Bellotti et al. [4], Lo Presti and O'Neill [18]): $C_{s}=84, C_{p}=133$ (these values hold when velocities are in $\mathrm{m} / \mathrm{s}$ and stresses in $\mathrm{kPa}) ; n=0.115 ; F(e)=(2.17-$ $-e)^{2} /(1+e)$.

The values of relative density obtained from the inversion of eqs (1) and (2) are reported in Fig 4 for LD and HD samples. 
The local check of the soil density was performed by means of thermal and electrical conductivity tests (Bellotti et al. [21]). Thermal conductivity tests can be performed in dry and saturated samples, whereas the electrical-resistivity tests can only be performed in saturated samples. The results obtained from thermal conductability tests, in the case of dry samples, are reported in Fig 4. Thermal and electrical measurements, in the case of wet samples, were not successful and are not considered. A possible explanation of this was the fact that the calibration curves for the test interpretation refer to fully saturated soils. It is reasonable to admit that the sand model under consideration did not meet such condition as explained later on.

Three CPT's (Tests No 1, 2 and 3) were performed for the HD sample in dry conditions after sample completion. Three tests (Tests No 4,5 and 6) were performed for the LD sample in dry conditions after sample completion. Other two tests were performed for LD wet sample, after the execution of cyclic loading. The relative density was inferred from the measured point resistance $q_{c}$ by means of the following equation [22]:

$$
D_{R}=-66.5+61.5 \cdot \log _{10}(X)
$$

where: $X=\left(q_{c} / \mathrm{p}_{\mathrm{a}}\right) /\left(\sigma_{\mathrm{v}}^{\prime} / \mathrm{p}_{\mathrm{a}}\right)^{0.52}$ is dimensionless; $p_{a}$ - atmospheric pressure is expressed in a consistent unit system.

The values of $D_{R}$ inferred from CPT's are reported in Fig 4.

In the case of HD sample, similar values of $D_{R}$ were obtained from different experimental methods (seismic tests, CPT's, thermal tests). On average the relative density resulted to be equal to about $85 \%$. In the case of LD sample it was possible to assess that $D_{R}$ was very low (from 15 to $30 \%$ ) close to the boundaries and of about $45 \%$ in the sample core. CPT's (Tests No 7 and 8 ) were performed after the execution of cyclic loading and exhibit a certain increase of due to soil compaction especially in the first $50 \mathrm{~cm}$ below the model foundation where $D_{R}$ ranges from 75 to $60 \%$. At a depth of $2 \mathrm{~m}$ below the foundation is of about $50 \%$.

Seismic tests were also performed to check the saturation condition of the two samples by comparing the compression wave velocities recorded before and after the soil saturation stage. The measurements show that, after sample saturation, $V_{p}$ does not approach the velocity of sound in water (from 1660 to $1700 \mathrm{~m} / \mathrm{s}$ ), as it would be in the case of a fully saturated sand, but decreases with the consolidation stresses. On the basis of these observations, the degree of saturation should be about $90 \%$ for both samples (Ishihara et al. [23], Black \& Lee [24], Strachan [25]).

The target values for the vertical load were 300 and $100 \mathrm{kN}$ for HD and LD samples respectively. These values represent typical design pressure levels for shallow foundations on sand.

The load was applied to the foundation by linear steps of about $50 \mathrm{kN}$ for dense sand and of about 15 $\mathrm{kN}$ for loose sand. After each step, the loading process was stopped up to complete stabilisation of creep deformations. An unload-reload loop was also performed. Fig 5 shows the load-displacement curves. The settlement reported in the Figure is that measured at the end of each loading step for the HD sample. The final vertical settlement experienced by the foundation was of about $7 \mathrm{~mm}$ for the HD sample and of about $16 \mathrm{~mm}$ for the LD sample.
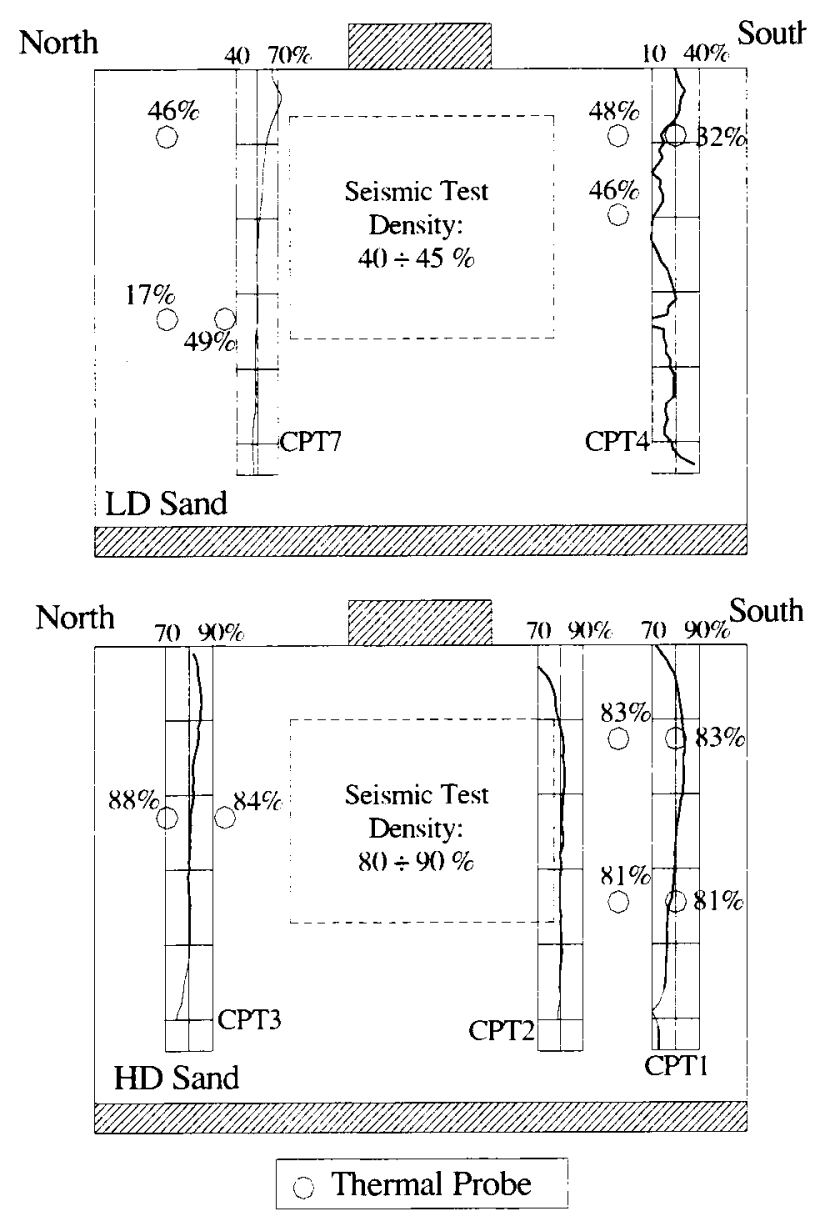

Fig 4. Relative density inferred from various tests 


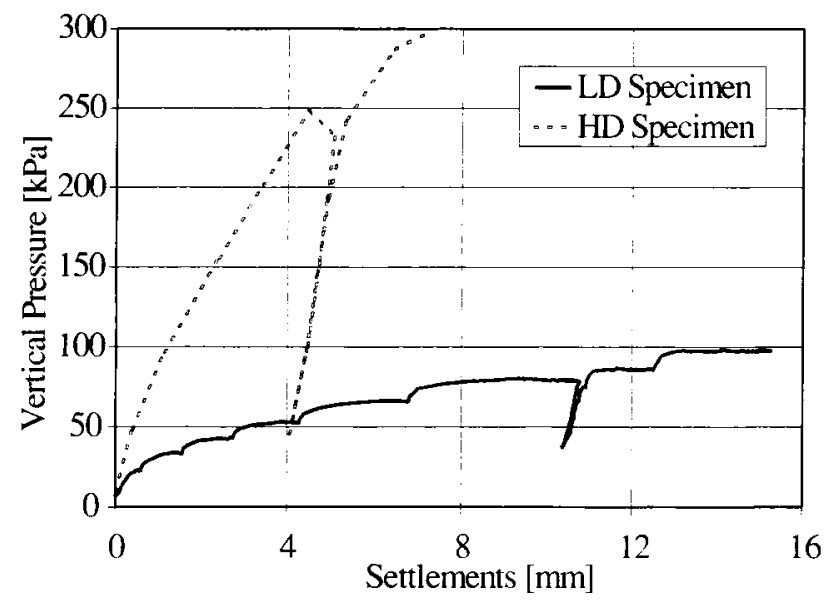

Fig 5. Load-displacement curves

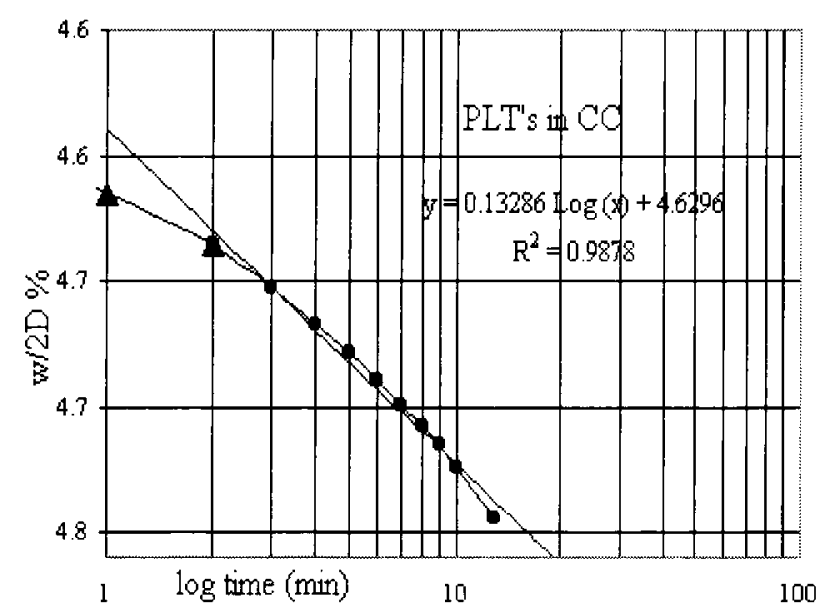

Fig 5a. w/2D vs. logt.

\section{Test interpretation}

\subsection{Displacements}

The observed settlements were compared to those computed using the CPT based approach due to Schmertmann [6] and subsequently refined by Hartman [7].

This approach considers a depth of influence, equal to two times the foundation width $B$ for square footing. The soil layer having thickness $2 B$ is subdivided in strata of height $\Delta z$. The total settlement ( $w$ ) is computed by means of the following expression:

$$
w^{\prime}=C_{1} \cdot C_{2} \cdot \Delta q \cdot \sum \frac{I_{z} \cdot \Delta z}{E}
$$

where: $\Delta q=q-\sigma_{1}^{\prime}$, i.e. net pressure increment $\left(\sigma_{v}^{\prime}\right.$. vertical effective stress acting at the foundation depth);
$C_{1}=\left(1-0.5 \sigma_{v}^{\prime} / \Delta q\right)$ is a correction factor that takes into account the embedment depth; $C_{2}=(1+0.2 \log t / 0.1)$ is the secondary settlement coefficient; $I_{z}$ is the influence factor that mimics the strain distribution into the soil mass; $E=2.5 q_{\mathrm{c}}$ is the soil stiffness.

For the HD sample the $q_{c}$ obtained from test results was used. For the LD sample it was decided to use a cone resistance as obtained from eq. (3) in the case of $D_{R}=35 \%$. In fact, the $q_{c}$ from tests 4,5 and 6 is too low because is referred to a looser zone of the sample, while the $q_{c}$ from tests 7 and 8 is too high because it was obtained after densification induced by cyclic loading.

The strain factor $I_{\bar{t}}$ values suggested by Hartman [7] are sligthly different than those proposed by Schmertmann [6] and result to be dependent on the soil density and embedment depth. For the case under consideration the use of the $I_{z}$ values suggested by Hartman [7] leads to smaller values of the computed settlement. The computed settlement values reported in the following have been obtained according to Schmertmann [6].

The secondary settlement for the recently deposited sand bed cannot be computed by means of the $C_{2}$ factor that assume a primary consolidation time of 0.1 year and a conventional increase of $20 \%$ of the consolidation settlement per each log cycle of time exceeding the consolidation time. For the case under consideration the secondary settlement was computed assuming a conventional consolidation time of 2 minutes and using the $C_{\alpha \varepsilon}$ values inferred from the long term stage of PLT's in CC. In particular, $C_{\alpha \varepsilon}$ is the slope of the interpolating line of the $w / 2 B$ vs. $\log t$ data for each loading step. From the interpretation of the PLT's in CC resulted that 2 minutes were appropriate to define the end of primary settlement (see Fig 5a).

PLT's in CC have been performed by using a deeply embedded rigid circular steel plate of $104 \mathrm{~mm}$ in diameter. Load increments of $50 \mathrm{kPa}$ have been applied to the plate. For each loading step, the secondary settlement has been observed during a period variable from 10 to 120 minutes. The $C_{\alpha \varepsilon}$ values are plotted in Fig 6 as a function of the applied load $(q)$. Two 


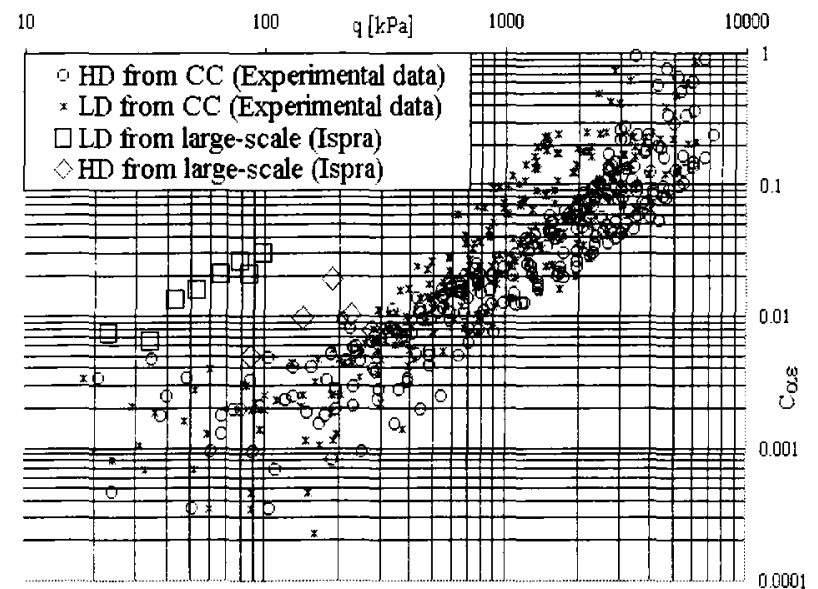

Fig 6. Secondary compression coefficient $C_{\alpha \varepsilon}$ from PLT's in CC

different symbols have been used to identify two different classes of relative density. The $C_{\alpha \varepsilon}$ values inferred from the two large scale experiments here described are also shown in Fig 6.

The scatter in the $C_{\alpha \varepsilon}$ values shown in Fig 6 is due to experimental errors and to differences in the mobilised shear stress. In order to reduce the observed scatter the $C_{\alpha \varepsilon}$ values have been replotted as a function of the mobilisation factor $q / q_{L I M}$ (Fig 7). The limit pressure ( $q_{\text {LIM }}$ ) has been computed for the shallow and deep foundations by means of the Brinch Hansen [26] and Berezantsev et al. [27] theories respectively. The angle of shear resistance for the above computations was inferred by means of the Bolton [28] empirical approach. In the case of deep PLT's in CC the limit pressure was also inferred from extrapolation

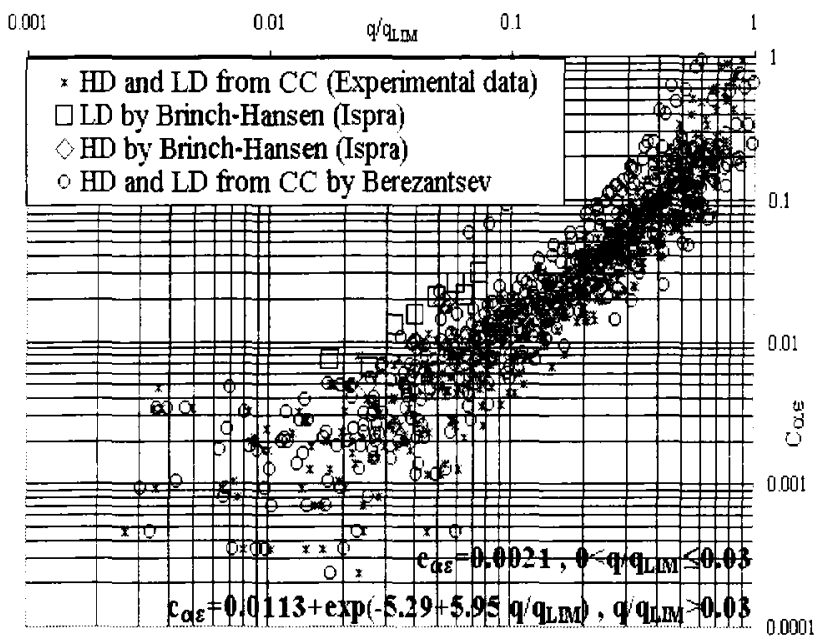

Fig 7. Secondary compression coefficient $c_{\alpha \varepsilon}$ from PLT's in CC of the experimental data assuming a hyperbolic law for the pressure-settlement curve. It is possible to see an almost unique trend of the observed $C_{\alpha \varepsilon}$ values vs. $q / q_{L I M}$ even though the data from Ispra tests represent an upper bound. Experimental errors and uncertainties of the adopted bearing capacity models may be responsible of the scatter observed in Fig 7.

The secondary settlement was computed considering that any perturbation, that is any load increment, produces additional creep deformations (Tatsuoka et al. 2000 [29]). Computation was therefore done according to the following equation:

$$
w_{s}=2 B \cdot \sum_{1}^{n} c_{\alpha \varepsilon}\left(q / q_{l i m}\right) \cdot \log t / t_{C}
$$

where: $w_{s}$ is the secondary settlement, $n$ is the number of loading steps, $t$ is the duration of each loading step (i.e. the time elapsed since the application of the load increment until the end of the test) and $t_{c}$ is a conventional primary consolidation time taken equal to 2 minutes after load stabilisation.

The secondary compression coefficient is a function of $q / q_{L I M}$ according to the equations reported in Fig 7.

The immediate and long term settlements for LD and HD samples are shown in Table 2. As far as the measured settlement is concerned, the long term settlement is that occurring after a conventional consolidation time of 2 minutes subsequent to the stabilisation of the applied load.

Table 2. Comparison between computed and observed settlements

\begin{tabular}{|c|c|c|c|c|c|c|c|c|}
\hline \multicolumn{7}{|c|}{} & \multicolumn{3}{|c|}{ Computed $w(\mathrm{~mm})$} & \multicolumn{4}{|c|}{ Measured $w(\mathrm{~mm})$} & \multicolumn{2}{|c|}{} \\
\cline { 2 - 10 } & $\begin{array}{c}\text { Imme- } \\
\text { diate }\end{array}$ & $\begin{array}{c}\text { Long } \\
\text { term }\end{array}$ & Total & $\begin{array}{c}\text { Imme- } \\
\text { diate }\end{array}$ & $\begin{array}{c}\text { Long } \\
\text { term }\end{array}$ & Total & $I_{4}$ & $C_{i}$ \\
\hline HD & 4.2 & 4.4 & 8.6 & 4.7 & 2.0 & 6.7 & 0.483 & 0.5 \\
\hline LD & 8.2 & 7.2 & 15.4 & 8.3 & 7.2 & 15.5 & 0.483 & 0.5 \\
\hline
\end{tabular}

Data in Table 2 show a good agreement between computed and observed settlements.

\subsection{Stiffness}

An operational Young's modulus was computed from load-settlement curves under the hypothesis of homogeneous, isotropic, elastic behaviour. 
The following equation was used to compute $\mathrm{E}$ :

$$
w=\frac{q}{E}\left(1-v^{2}\right) \cdot B \cdot I_{w} \cdot f(z)
$$

where: $B=$ footing width; $I_{\mathrm{u}}=0.7$ is the influence factor for a rigid plinth that depends on the footing shape and compressible layer thickness; $f(z)=0.9$ takes the foundation embedment into account; $v=$ Poisson's ratio taken equal to 0.2 .

The computed values of $E$ were divided by the small strain Young's modulus $\left(E_{0}\right)$ determined by means of the following equation (Hoque et al. [30]):

$$
E_{o}=1510 \frac{(2.17-e)^{2}}{(1+e)} \sigma_{1}^{0.53} \cdot p_{a}^{0.47}
$$

where: $e$ is the void ratio and $p_{a}$ is a reference pressure.

The $E_{0}$ values have been computed by means of equation (7) making reference to the $\sigma_{1}^{\prime}$. existing at the depth of $1 \mathrm{~m}$ below the foundation.

Equation (6) was also used to compute the unload-reload Young's modulus $E_{U R}$ from unload-reload loops. In this case, the pressure and displacement $(q$ and $w$ ) were replaced by the corresponding relevant increments $\mathrm{D} q$ and $\mathrm{D} w$. The values of $E_{U R}$ were divided by $E_{0}$. This latter was computed by means of equation (7) assuming $\sigma_{v}^{\prime}=0.5\left(\sigma_{A}^{\prime}+\sigma_{B}^{\prime}\right)$. The value of $\sigma_{v}^{\prime}$, used, corresponds to the average effective vertical stress existing at a depth of $1 \mathrm{~m}$ beneath the footing during the unload-reload loop in Fig 5.

The $E / E_{0}$ and $E / E_{U R}$ values as function of $w / B$ are reported in Fig 8.

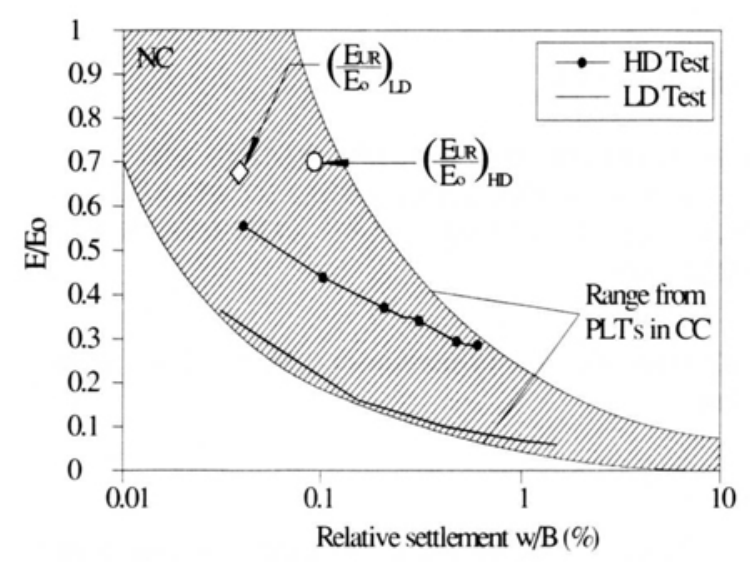

Fig 8. $E / E_{0}$ Dec
The values inferred from the CC PLT's performed in Ticino sand (Ghionna et al. [5]) are also plotted in the same Figure.

The data from PLT's show a certain scatter especially at small strains. This scatter is mainly due to experimental errors. However, different test conditions (number of loading steps, time allotted for each step, etc.) produce different creep settlements, which could be another explanation for the observed scatter. The $E / E_{0}$ vs. $w / B$ curves obtained from lspra tests well compare to those inferred from PLT's in CC.

\section{Conclusions}

The following conclusions can be drawn from the above exposed data:

- the Schmertmann [6] method is capable of providing an excellent prevision of the primary settlement occurring in the freshly deposited Ticino sand.

- the experimentally observed creep settlement is relevant and mainly depend on the number of loading steps and duration of each step.

- the $C_{\alpha \varepsilon}$ coefficient mainly depends on the mobilisation factor or inverse of safety factor $q / q_{L I M}$.

- computation of the secondary settlement by means of empirical approach requires the knowledge of the primary consolidation time, loading history and $C_{\alpha \mathcal{E}}$ coefficient.

- a similar stiffness decrease ( $E / E_{0}$ vs. relative settlement) was observed for shallow and deep experiments. In particular, for a relative settlement of $0.1 \%$ (i.e. a typical value for well designed foundation on sands) the stiffness is, on average, $50 \%$ of the initial value $\left(E_{0}\right)$.

\section{References}

1. SGI, Studio Geotecnico Italiano. Physical model of a shallow foundation resting on a sand bed subjected to static and cyclic loading. Contract No 123379611 F1ED ISP I, 1998.

2. P. Negro, G. Verzeletti, J. Molina, S. Pedretti, D. Lo Presti \& S. Pedroni. Large-Scale Geotechnical Experiments on Soil-Foundation Interaction (TRISEE Task 3) // Special Publication No I.98.73 of European Commission, Italy, Joint Research Centre Ispra (VA), 1998.

3. S. Pedretti. Non-Linear Seismic Soil-Foundation Interaction: Analysis and Modelling Methods. PhD. Department of Structural Engineering, Politecnico di Milano, Italy, 1998. 
4. R. Bellotti, M. Jamiolkowski, D. C. F. Lo Presti \& D. A. O'Neill. Anisotropy of Small Strain Stiffness in Ticino Sand // G., technique, 46(!). 1996, p. 115-131.

5. V. N. Ghionna, M. J.'niolkowsk, S. Ironi \& R. Salgado. The tip displacement of drilled sharts in sands // Settlement 94, ASCE Specialty Conference, 1994.

6. J. H. Schmertmann. Static Cone to Compute Static Settlements over Sand // JSMFE Div., ASCE, 96(SM3), 1970, p. 1011-1046.

7. J. Hartman. Finite element parametric study of vertical strain influence factors and the pressuremeter test to estimate the settlement of footings in sand. PhD. Department of Civil Engineering, the University of Florida, 1974.

8. E. Rondena. Analisi morfologiche della sabbia del Ticino. ENEL CRIS Internal Report, Milano, Italy, 1984.

9. G. Baldi, R. Bellotti, V. Crippa, C. Fretti, V. N. Ghionna, M. Jamiolkowski, D. Ostricati, E. Pasqualini \& S. Pedroni. Laboratory Validation of In-Situ Tests Geotechnical Engineering in Italy-An Overview // ISSMFE Golden Jubilee, XI ICSMFE, San Francisco, Ca., 1985.

10. G. Baldi, R. Bellotti, V. N. Ghionna, M. Jamiolkowski \& E. Pasqualini. Interpretation of CPT's and CPTU's // IV Internationa Geotechnical Seminar, Nanyang Technological Institute-Singapore, 1986.

11. G. Baldi, R. Bellotti, V. N. Ghionna, M. Jamiolkowski \& D. C. F. Lo Presti. Modulus of Sands from CPT's and DMT's // Proc. XII ICSMFE, Rio de Janeiro, 1989.

12. R. Bellotti, V. Crippa, V. N. Ghionna \& S. Pedroni. Saturation of Sand Specimen for Calibration Chamber Test // Proc. ISOPT I, Orlando, Fla, 1988

13. D. C. F. Lo Presti, O. Pallara, R. Lancellotta, M. Armandi \& R. Maniscalco. Monotonic and Cyclic Loading Behaviour of Two Sands at Small Strains // Geotechnical Testing Journal, 16(4), 1993, p. 409-424.

14. R. Passalacqua. A Sand-Spreader Used for the Reconstitution of Granular Soils Models // Soils and Foundations, 31(2), 1991, p. 175-180.

15. F. Tatsuoka. M. Okahara, T. Tanaka, K. Tani, T. Morimoto \& M.S. Siddique. Progressive failure and Particle Size Effect in Bearing Capacity of a Footing on Sand // Proc. Geotechnical Engineering Congress. Geotechnical Special Publication, No 27, Vol II, ASCE, New York, 1991, p. $788-801$.

16. C. Fretti, D. C. F. Lo Presti \& R. Salgado. The Research Dilatometer: In Situ and Calibration Chamber Test Results // Rivista Italiana di Geotecnica, XXVI(4), 1992, p. 237-243.

17. D. C. F. Lo Presti, R. S. Berardi, S. Pedroni \& V. Crippa. A New Traveling Sand Pluviator to Reconstitute Specimens of Well Graded Silty Sands // Geotechnical Testing Journal, 16(1), 1993, p. 18-26.

18. D. C. F. Lo Presti \& D. O' Neill. Laboratory Investigation of Small Strain Anisotropy in Sand // Proc. of ISOCCT1, Potsdam, NY, 1991, p. 213-224.

19. S. K. Roesler. Anisotropic Shear Modulus Due to StressAnisotropy // JGE Div. ASCE, 105(GT7), 1979, p. 871 880.
20. K. H. Stokoe, S. H. H. Lee \& D. P. Knox. Shear Moduli Measurement Under True Triaxial Stresses // Proc. Advances in the Art of Testing Soils Under Cyclic Condition, ASCE Convention, Detroit, Mich, 1985.

21. R. Bellotti, J. Benoit \& P. Morabito. A Self-Boring Electrical Resistivity Probe for Sands // Proc. XIII ICSMFE, New Delhi, India 13(1), 1994, p. 313-316.

22. G. M. Garizio. Determinazione dei parametri geotecnici ed in particolare di $\mathrm{Ko}$ da prove penetrometriche. M.Sc. Thesis, Department of Structural Engineering, Politecnico di Torino, 1997.

23. K. Ishihara, Y. Huang \& H. Tsuchiya. Liquefaction Resistance of Nearly Saturated Sand as Correlated with Longitudinal Wave Velocity // 2nd Int. Conference on Earthquake Geotechnical Engineering, Lisbon, June, 1999, in print.

24. D. K. Black \& K. L. Lee. Saturating Laboratory Sample by Back Pressure // Journal of the Soil Mechanics and Foundation Division, ASCE, Vol 99, No SM1, 1973, p. 75-93.

25. P. Strachan. Alternative Test Method for Ensuring Full Saturation in Triaxial Samples // Geotechnical testing Journal, GTJODJ, Vol 8, No 1, 1985, p. 43-46.

26. J. Brinch Hansen. A General Formula for Bearing Capacity. The Danish Geotechnical Institute, Copenhagen, Bull. n. $11,1970$.

27. V. G. Berezantsev, V. S. Khristorov \& V. N. Golubkow // Load Bearing Capacity and Deformation of Piled Foundations. V ICSMFE, Paris, 1961.

28. M. D. Bolton. The strength and Dilatancy of Sands. Cambridge Un. Eng. Dep. RR CUED/D Soils, TR152, 1984.

29. F. Tatsuoka, F. Santucci de Magistris, K. Hayano, Y. Momoya \& J. Koseki. Some New aspects of time effects on the stress strain behaviour of stiff geomaterials // Keynote Lecture, Proc. 2nd International Conference on Hard Soils and Soft Rocks, Napoli 1998, Balkema, Vol 2 (to appear).

30. E. Hoque, F. Tatsuoka, T. Sato \& Y. Kohata. Inherent and stress induced anisotropy in small strain stiffness of granular materials // Proc. Ist Int. Conf. of Earthquake Geotechnical Engineering. Tokyo, Vol 1, 1995, p. 277 282.

Iteikta 20000705

\section{EKSPLOATUOJAMO SMÉLIO STANDUMO NUSTATYMAS VYKDANT DIDELIO MASTO APKROVOS BANDYMUS ANT ATKURTO SME்LIO PAGRINDO}

\section{Gabrielaitis, M. Jamiolkowski, D. C. F. Lo Presti \& I. Puci}

\section{Santrauka}

Atlikus du didelio masto bandymus ant kvadratinio standaus pamato siekta nustatyti smèlio standumą. Pamato kraštiné $-1 \mathrm{~m}$. Betoninio kesono, kuriame $1 \mathrm{~m}$ gylyje buvo igilin- 
tas ir bandomas atskirasis pamatas, matmenys buvo $4,6 \times 4,6$ $\mathrm{m}$ (plane), aukštis $-4,05 \mathrm{~m}$. Du Ticino smèlio pavyzdžiai buvo paruošti esant dviem skirtingiems santykiniams tankumams: $D_{R} \cong 45$ ir $85 \%$. Mažo tankio smèlio bandymo atveju maksimali apkrova buvo apie $100 \mathrm{kPa}$. Didelio tankio smélio atveju ji buvo lygi apie $300 \mathrm{kPa}$.

Šios reikšmès sutampa su sekliujų pamatụ projektuojamomis apkrovu reikšmémis. Pamatas ant tankaus smèlio pagrindo buvo apkraunamas laipsniškai kas $50 \mathrm{kN}$ jèga, o ant mažo tankio - kas $15 \mathrm{kN}$ jèga. Po kiekvieno žingsnio apkrovimo procesas buvo sustabdomas, kad stabilizuotųsi valkšnumo deformacijos.

Bandymu metu stebètos nuosèdžių reikšmès buvo palygintos su reikšmèmis, gautomis atlikus nuosèdžių skaičiavimus pagal analizini metodą, kuris remiasi statinio zondavimo duomenimis. Šis metodas buvo pasiūlytas $1970 \mathrm{~m}$. Schmertmanno.

Schmertmannas suintegravo baigtinio gylio poslinkiu prieaugių skaičių ir itraukè: $C_{1}$ - pamato igilinimo faktorių; $C_{2}$ laiko efekto faktoriu. Deformaciju itakos faktoriaus funkcinè forma buvo nustatyta remiantis baigtinių elementų metodo analize. Suminiai nuosèdžiai buvo skaičiuojami pagal (4) formulę.

Schmertmanno metodas neịvertino galutinio nuosédžio. Pagrindinis trūkumas - (4) lygtis buvo taikoma neivertinus valkšnumo deformacijų, kurios ypač akivaizdžios atliekant mažo santykinio tankumo smélio bandymą.

Antrinis nuosèdis šviežiai supiltam ir atkurtam smèliui negali būti skaičiuojamas pagal $C_{2}$ koeficiento išraišką. Laikoma, kad pirminés konsolidacijos laikas yra 0,1 metu ir konsolidacijos nuosèdis išauga $20 \%$ kiekviename laiko logaritminès skalès cikle, viršydamas konsolidacijos laiką. Atsižvelgiant i tai, antrinis nuosèdis buvo skaičiuojamas imant pirminès konsolidacijos pabaigos laiką, lygu $2 \mathrm{~min}$, ir antrinès deformacijos koeficiento $C_{\alpha \varepsilon}$ reikšmes, gautas iš didelès trukmès plokštès apkrovos testŭ, atliktų kalibravimo kameroje (CC).

$C_{\alpha \varepsilon}$ yra interpoliacinès linijos kampas tarp $w / 2 B$ ir $\log (t)$ kiekviename apkrovimo žingsnyje.

Plokštes apkrovos testai kalibravimo kameroje buvo atliekami naudojant giliai itvirtintą, standžią, apvalią plieninę $104 \mathrm{~mm}$ skersmens plokštę.

$50 \mathrm{kPa}$ apkrovos prieaugis buvo uždedamas ant plokštès. Kiekviename apkrovimo žingsnyje antrinis nuosédis buvo tarp 10 ir $120 \mathrm{~min} . C_{\alpha \varepsilon}$ reikšmès, kaip apkrovos funkcija, yra pavaizduotos 6 pav.

$C_{\alpha \varepsilon}$ reikšmių išsibarstymas yra dèl eksperimento metu atsiradusių paklaidụ ir dèl skirtingos tangentinių itempimu mobilizacijos. Norint sumažinti išsibarstymą, $C_{\alpha \varepsilon}$ reikšmès buvo perskaičiuotos kaip mobilizacijos faktoriaus $q / q_{L I M}$ funkcija.

Ribinè apkrova $q_{L M M}$ sekliesiams pamatams buvo skaičiuojama pagal J. Brincho Hanseno [26] teoriją. Giliesiems pamatams buvo taikoma V. G. Berezantsevo [27] teorija. Grunto vidinès trinties kampams apskaičiuoti buvo taikomas M. D. Boltono [28] empirinis metodas. Ribinè apkrova apvalios plokštės apkrovimo bandymuose (CC) buvo nustatyta interpoliuojant eksperimentinius duomenis, apkrovos nuosèdžių kreivès pasiskirstymui taikant hiperbolinị dèsni. 7 pav. galima pastebèti beveik dèsningą duomenu pasiskirstymą gautoms $C_{\alpha \varepsilon}$ su $q / q_{L S,}$ reikšmèmis. Duomenys iš sekliojo pamato testu taip pat rodo suartéjimą. Dél eksperimentu metu atsiradusių paklaidu ir idiegtu ribinès apkrovos nustatymo modelių 7 pav. matyti duomenų išsibarstymas.

Antrinis poslinkis buvo skaičiuojamas laikant, kad kiekvienas apkrovos prieaugis po kiekvienos valkšnumo fazès sukelia papildomą valkšnumo deformaciją. Todèl skaičiavimas buvo atliekamas pagal (5) lygti. Pirminiai ir antriniai nuosédžiai skirtingu tankių sméliams pateikti 2 lenteleje, iš kurios matyti geras sutapimas tarp stebètų ir apskaičiuotu nuosèdžių.

Tamprumo modulis buvo apskaičiuotas iš apkrovos nuosèdžių kreivès, laikantis hipotezès, kad gruntas yra homogeninis, izotropinis, tamprus. Apskaičiuotos tamprumo modulio reikšmès buvo padalytos iš mažų deformacijų srities Jango modulio $E_{0}$, kuris buvo nustatytas pagal (7) lygti. Pagal (6) lygti buvo nustatytas nukrovimo-apkrovimo tamprumo modulis iš nukrovimo-apkrovimo eksperimentinès apkrovos - nuosèdżių grandinès. $E / E_{0}$ ir $E / E_{U R}$ reikšmès yra pavaizduotos 8 pav. kaip w/B funkcija. 8 pav. pavaizduotos ir nustatytos tamprumo modulio reikšmès iš kalibravimo kameros testų, kurios rodo tam tikrą išsibarstymą, ypač mažu deformacijų srityje. Skirtingos testų sąlygos (apkrovimo žingsnių skaičius, kiekvieno apkrovimo žingsnio stabilizacijos laikas ir t. t.) sukèlè skirtingus valkšnumo deformacijos nuosédžius. Tuo galima paaiškinti atsiradusi išsibarstymą.

Linas GABRIELAITIS. PhD student. Dept of Building Structures. Vilnius Gediminas Technical University (VGTU), Saulètekio al. 11, LT-2040 Vilnius, Lithuania. E-mail: gabrieliui@takas.lt

Research interests: application of computer-aided design systems in geotechnical engineering, and interaction between ground and foundations.

Michele JAMIOLKOWSKI. Professor. Dept of Structura and Geotechnical Engineering. Politecnico di Torino, Corso Duca degli Abruzzi 24, 10129 Torino, Italy. E-mail: sgi_jamiolkowski@studio-geotecnico.it

ISSMFE President for period 1994-7. Chairman of the present International Technical Committee for the Preservation of the Leaning Tower of Pisa.

Diego C. F. Lo PRESTI. Doctor, Associate Professor. Dept of Structural and Geotechnical Engineering. Politecnico di Torino, Corso Duca degli Abruzzi 24, 10129 Torino, Italy. E-mail: diego@geohp.polito.it

Ignazio PUCI. Doctor. Dept of Structural and Geotechnical Engineering. Politecnico di Torino, Corso Duca degli Abruzzi 24, 10129 Torino, Italy. E-mail: puci@athena.polito.it 